\title{
DIGITAL DIVIDE PEREMPUAN INDONESIA
}

\author{
Neni Wahyuningtyas dan Khofifatu Rohmah Adi \\ Program Studi S1 Pendidikan IPS, Fakultas Ilmu Sosial, Universitas Negeri Malang
}

\begin{abstract}
Abstrak: Kehadiran teknologi informasi dan komunikasi selama ini telah membawa perubahan bagi masyarakat. Hal itu membawa konsekuensi berupa masalah digital divide bagi negaranegara berkembang seperti Indonesia. Selama ini peran perempuan dalam perkembangan teknologi informasi masih belum banyak jika dibandingkan dengan laki-laki. Ada beberapa faktor yang menyebabkan digital divide kaum perempuan yaitu tingkat ketrampilan dan pendidikan, masalah bahasa, keterbatasan waktu, adanya stereotipe seksi yang disematkan pada perempuan sehingga mudah dilecehkan, dan norma budaya serta sosial yang berkembang. Mengingat pentingnya masalah ini, sudah saatnya untuk melakukan tindakan guna memastikan bahwa perempuan di Indonesia dapat mengaktifkan dirinya di era informasi. Adapun upaya untuk mempersempit digital divide pada perempuan diantaranya literasi informasi, menghilangkan diskriminasi gender, membangun kebijakan dan budaya gender yang transformative, dan meningkatkan skill dan kompetensi dengan Bimtek TIK.
\end{abstract}

Kata kunci: teknologi komunikasi dan informasi, digital divide, perempuan Indonesia

\begin{abstract}
Information dan communication technology has bought changes in our society. Along with its development, many concequences occur in developing countries as well as Indonesia. Women role in the development of information and communication technology is lesser than men. There are many factor causing the digital divide of Indonesian women i.e. skill and education level, language problem, lack of time, sexist stereotype, social and cultural norms. Considering to this issue, it is important to take action to ensure women in Indonesia to be more active and involve in the development of information and communication technology. There are many ways to decrease the digital divide of Indonesian women i.e. information literacy, eliminating gender discrimination, transformative and gender responsive policy, increasing women skill and competency trough education and training.
\end{abstract}

Key words: Information dan communication technology, digital devide, Indonesian women.

Sekarang ini perkembangan teknologi informasi dan komunikasi (TIK) telah berkembang secara pesat. Adanya teknologi informasi dan komunikasi memudahkan masyarakat untuk belajar dan mendapatkan informasi yang mereka butuhkan dari mana saja, kapan saja dan dari siapa saja. Ketika informasi telah menjadi suatu komoditas penting dalam kehidupan manusia, masyarakat telah masuk ke dalam satu era baru yakni era masyarakat infomasi. Era di mana masyarakat tidak lagi mau ketinggalan informasi, sehingga masyarakat dianggap aktif dalam menggunakan media untuk suatu tujuan tertentu. Perubahan ini tentu saja didorong oleh perkembangan teknologi komunikasi yang membuat arus informasi sedemikian cepat, hingga jarak tidak lagi membatasi transfer informasi.
Kehadiran TIK misalnya internet dalam perkembangan selama ini, telah membawa perubahan bagi masyarakat. Hanya saja, digital divide khususnya di negaranegara berkembang seperti Indonesia masih menjadi masalah yang harus dipecahkan. Digital divide dapat dipahami sebagai pembagian kelompok atas kemampuan terhadap penguasaan ekonomi informasi digital. Pembagian ini sangat berkaitan dengan klasifikasi antara negara maju dan negara berkembang, sehingga pada satu titik ditemukan bahwa digital divide sangat erat kaitannya dengan development divide.

Hasil riset UNDP (2011) menunjukkan jika di Indonesia pemanfaatan TIK masih rendah, hal ini terlihat pada ren- 
dahnya penetrasi internet dan tingkat $\mathrm{Hu}$ man Development Index (HDI) di tahun 2011 yang baru mencapai indeks 0,684 atau berada di urutan ke-108 dan termasuk dalam kategori medium human development. Rendahnya tingkat HDI Indonesia salah satunya disebabkan oleh ICT Development Index (IDI) yang juga rendah. Kondisi tersebut semakin sulit dengan adopsi TIK yang berbeda antara daerah pedesaan dan perkotaan. Penggunaan internet oleh masyarakat Indonesia di daerah perkotaan mencapai $83,4 \%$ sedangkan di perdesaan hanya $16,6 \%$ (ITU, 2014). Selain itu sesuai data yang dirilis Asosiasi Penyelenggara Jasa Internet Indonesia (APJII) dan Pusat Kajian Komunikasi Universitas Indonesia, pada tahun 2015 jumlah pengguna internet di Indonesia sudah mencapai 88,1 juta atau $34,9 \%$ dari total 252,4 juta penduduk.

Masalah tersebut nampaknya tidak berhenti disitu saja, ada masalah lain yang mengiringi yaitu peran perempuan dalam perkembangan teknologi informasi masih lebih sedikit dibandingkan dengan banyaknya jumlah laki-laki yang masih memegang peranan penting dalam teknologi informasi. Hasil pemaparan data Kementrian Pemberdayaan Perempuan dan Perlindungan Anak (KPPPA), saat ini hanya sedikit kaum perempuan yang memiliki pengetahuan, kemampuan dan kesempatan untuk memahami TIK. Hal ini terjadi karena rendahnya rasa percaya diri perempuan terhadap permasalahan-permasalahan teknologi.

Semestinya kondisi global dari perkembangan teknologi informasi menuntut para pekerja perempuan di bidang teknologi informasi untuk menciptakan, menerapkan, dan menggunakannya secara maksimal. Nampaknya pekerjaan yang berkaitan dengan ruang publik, peran perempuan dalam ketenagakerjaan TIK kita lihat lebih mendominasi pada posisi administrasi, seperti menangani surat elektronik, memasukkan data, operator komputer, dan sejenisnya. Selain itu pemanfaatan internet oleh perempuan di Indonesia selama ini masih terbatas pada kegiatan mencari informasi sesuai topik yang diminati dan kebutuhan bersosialisasi saja. Hal tersebut tentunya menyebabkan kaum perempuan tidak mampu berkembang lebih jauh untuk melanjutkan pendidikan dan bekerja.

Seperti hasil riset Accenture tahun 2016 dengan judul "Menjadi Sederajat: Bagaimana Digital Membantu Mempersempit Celah Jender di Ruang Lingkup" disebutkan jika kefasihan digital perempuan Indonesia berada di peringkat paling rendah dari 26 negara yang turut di survey. Selain itu, Indonesia juga berada di peringkat ke21 dari 26 negara yang perempuannya tidak menyadari manfaat digital dapat mendukung pekerjaan mereka (Kompas, 31 Maret 2016).

\section{INFORMASI PERKEMBANGAN TEKNOLOGI DAN KOMUNIKASI}

TIK tidak bisa dipisahkan dari kehidupan manusia saat ini. Mulai dari anak kecil hinga orang tua, pedagang kecil hingga pengusaha besar, baik disadari maupun tidak sudah begitu tergantung pada TIK. Teknologi informasi adalah seperangkat alat yang membantu manusia bekerja dengan informasi dan melakukan tugas-tugas yang berhubungan dengan pemrosesan informasi (Haag dan Keen, 1996). Teknologi Informasi dibuat untuk mempermudah aktivitas manusia dalam berbagai hal terutama untuk berkomunikasi. Pada awalnya teknologi ini digunakan sebagai pengganti penyampaian informasi secara manual dari mulut ke mulut. Dengan berkembangnya ilmu pengetahuan maka teknologi informasi ini mampu menyampaikan informasi dengan kapasitas yang banyak, cepat serta dapat disimpan dalam waktu yang lama. 
Menurut Martin (1999), teknologi informasi tidak hanya terbatas pada teknologi komputer (perangkat keras dan perangkat lunak) yang akan digunakan untuk memproses dan menyimpan informasi, melainkan juga mencakup teknologi komunikasi untuk mengirim/menyebarkan informasi. Pendapat ini juga sama halnya seperti yang dijelaskan oleh Williams dan Sawyer (2003), bahwa teknologi informasi adalah teknologi yang menggabungkan komputer dengan jalur komunikasi kecepatan tinggi yang membawa data, suara, dan video.

Saat ini teknologi informasi dan komunikasi telah berkembang hingga dapat menghubungkan antara beberapa media seperti televisi, komputer, telepon selular dan banyak lagi. Seperti halnya komputer saat ini telah dapat terhubung antara komputer satu dengan komputer lainnya berkat adanya jaringan internet.

Menurut Dholakia dan Kshetri (2003), sebagai produk sosial, berbagai teknologi, termasuk internet bersifat tidak bebas nilai atau budaya. Tingkat kompabilitas antara nilai dan norma teknologi dengan nilai atau norma (yang dianut) penggunanya sangat menentukan pola penggunaan teknologi tersebut. Nilai dari sebagian besar barang dan jasa TIK cenderung lebih maskulin dibandingkan feminin dan hal ini merupakan salah satu penyebab digital divide yang terkait jender. Lebih lanjut Dholakia dan Kshetri (2003) menyebutkan bahwa laki-laki dan perempuan mempunyai perbedaan budaya, terspesialisasi dalam pekerjaan yang berbeda, serta mempunyai keinginan-keinginan yang berbeda. Perbedaan-perbedaan tersebut berinteraksi dengan fitur-fitur dari teknologi modern seperti internet sehingga mempengaruhi adopsi dan penggunaan internet. Hasil analisisnya juga menunjukkan bahwa ketidaksetaraan jender yang diukur dengan proporsi pengguna internet antara laki-laki dan perempuan cenderung semakin tidak proporsional. Faktor-faktor kultural mempengaruhi keterlibatan perempuan dalam pengambilan keputusan pada berbagai tingkat yaitu rumah tangga, organisasi, dan tingkat nasional.

Enochsson (2005) menjelaskan jika laki-laki lebih tertarik mengenai teknologi internet, sedangkan perempuan lebih tertarik dengan apa yang bisa dilakukan dengan internet. Hasil penelitian Gefen dan Straub (1997) menunjukkan bahwa jender mempengaruhi keberadaan sosial dari internet, persepsi kemudahan menggunaan email, dan persepsi manfaat email. Persepsi perempuan mengenai keberadaan sosial dari email adalah lebih tinggi dibandingkan dengan laki-laki. Persepsi manfaat internet juga lebih tinggi dilihat oleh perempuan dibandingkan laki-laki, tetapi laki-laki cenderung lebih mudah menggunakan email dibandingkan perempuan. Ramilo (2002) menyebutkan bahwa dampak teknologi informasi dan komunikasi (TIK) terhadap perkembangan ekonomi, politik, dan sosial sudah menjadi perhatian utama di beberapa negera di Asia. Dalam sepuluh tahun terakhir banyak negara mengembangkan strategi dan kebijakan yang sebagian besar dititikberatkan pada pelaksanaan kebijakan dan strategi bidang ekonomi yang memberikan promosi daya tarik untuk industri TIK, termasuk deregulasi industri telekomunikasi, menarik investor asing, dan meningkatkan konektivitas internet. Namun demikian menurut Ramilo (2002) meskipun terjadi kemajuan pada industri TIK, keuntungan dari TIK tidak bisa dinikmati oleh sebagian besar masyarakat, terutama di negara-negara berkembang. Difusi teknologi komunikasi dan internet sebagian besar terkonsentrasi di perkotaan, masyarakat berpendapatan tinggi, dan orang-orang berpendidikan saja. Perempuan sendiri secara umum terpinggirkan yang sebagian besar tidak memiliki daya beli dan tidak punya akses ke alat komunikasi modern. 
Dalam satu dasawarsa pengguna internet di dunia meningkat drastis dari $0,4 \%$ pengguna dari seluruh penduduk dunia di tahun 1995 menjadi hampir 60 kali lipat pada tahun 2008. Tahun 2008 pengguna internet mencapai $23,33 \%$ peduduk dunia. Namun sangat disayangkan bahwa penguasaan teknologi informasi Indonesia hanya sebesar $13 \%$, masih kalah dengan negara-negara tetangga. Berikut ini disajikan tabel penguasaan informasi teknologi bidang internet oleh perempuan di berbagai negara. Dari tabel tersebut dapat diketahui dengan jelas bagaimana posisi peran perempuan Indonesia dalam bidang TIK yang sangat minim. Ranking 88 yang ditempati Indonesia menunjukkan jika fenomena kesenjangan kapasitas dan kapabilitas dalam penguasaan teknologi informasi khususnya internet oleh kaum perempuan lebih disebabkan oleh adanya ketimpangan budaya, sosial dan ekonomi.

Tabel 1. Penguasaan Informasi Teknologi Bidang Internet oleh Perempuan (Sumber: ITU, 2014)

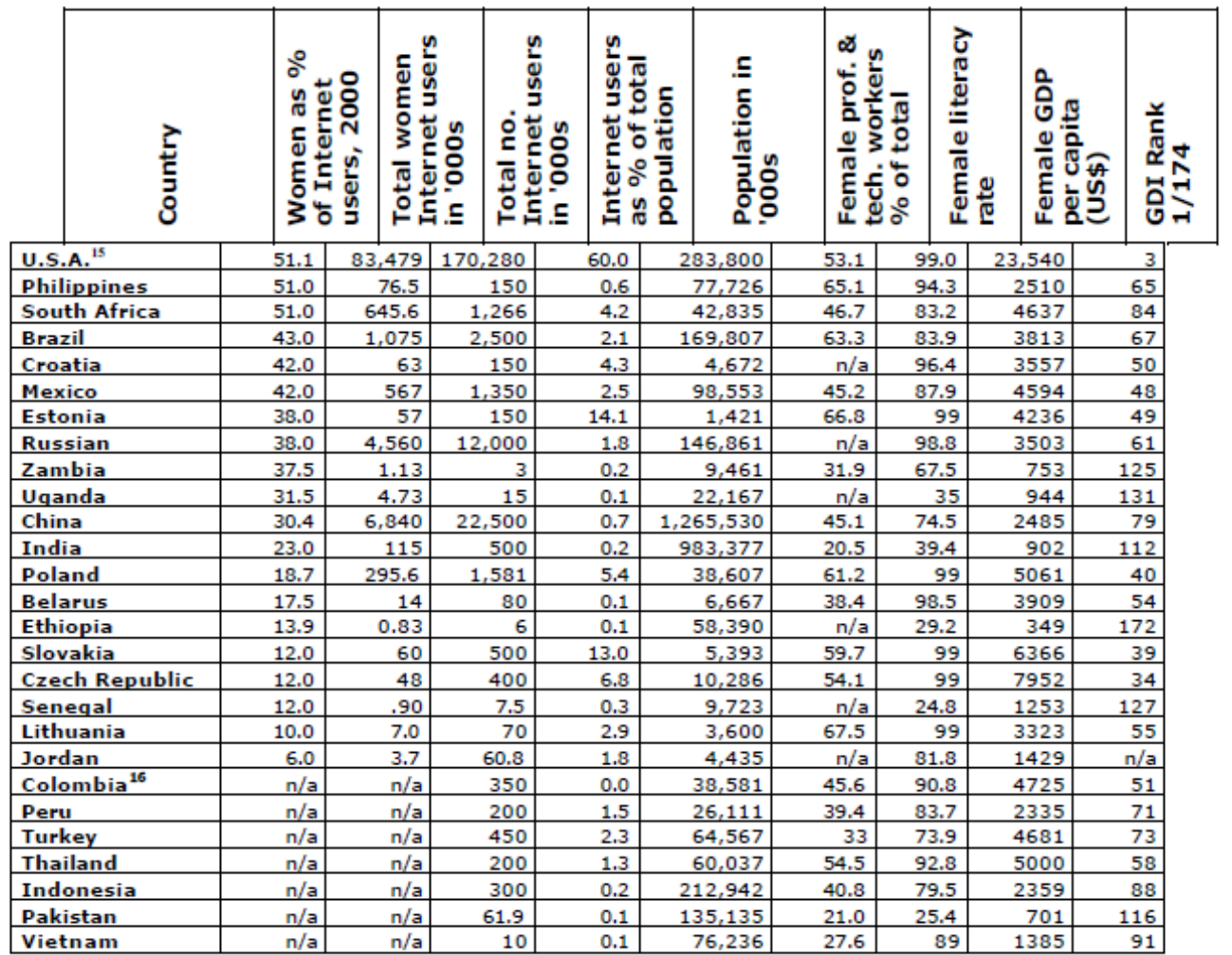

\section{DIGITAL DIVIDE}

Masalah kesenjangan telah menjadi isu yang sangat banyak menuai berbagai macam perdebatan, yang pada dasarnya perihal bagaimana melihat kesenjangan itu. Penulis melihat bahwa kesenjangan digital memang sedang terjadi dan bukan mitos semata. Dengan mengembalikan divide ini pada konteks perekonomian, harus diingat bahwa Information and Communication Technology (ICT) berkaitan erat knowledge yang mana adalah aspek sangat penting dalam faktor produksi 
(Parayil, 2005). Hal ini jelas berimbas pada kapasitas ekonomi dan pendapatan negara, sehingga tidak mengherankan jika Parayil akhirnya menjadikan GDP menjadi salah satu bentuk nyata dari digital divide itu sendiri dan menilai bahwa kesenjangan digital tidak lain merupakan fenomena kesenjangan kapasitas dan kapabilitas dalam penguasaan teknologi informasi yang sangat berkaitan dengan ketimpangan sosial-ekonomi.

Menurut OECD tahun 2001 dijelaskan jika kesenjangan penguasaan teknologi informasi (digital divide) didefinisikan sebagai berikut "....the gap between individuals, households, businesses and geographic areas at different socio-economic levels with regard both to their opportunities to access information and communication technologie (IT) and to their use of the Internet for a wide variety of activities". Berdasarkan pengertian tersebut dapat disimpulkan bahwa kesenjangan digital merupakan ketidaksamaan dalam hal akses pada komputer dan internet antara kelompok yang didasarkan pada satu atau lebih identifikasi sosial dan kultural. Kesenjangan bisa terjadi antara tingkat individu, rumah tangga, bisnis, dan area geografi yang tingkat sosial ekonominya berbeda, berdasarkan kesempatan mereka untuk mengakses teknologi informasi dan komunikasi. Sebagai contoh kesenjangan digital adalah perbedaan akses pada komputer dan internet antara kelompok perempuan dan laki-laki, usia tua dan muda.

Secara umum penyebab terjadinya digital divide diantaranya:

a. Infrastruktur

Masalah kesenjangan digital (digital divide) di Indonesia sebenarnya banyak dipengaruhi oleh tidak meratanya pembangunan infrastruktur jaringan komunikasi dan regulasi di berbagai daerah. Adanya perbedaan pola hidup antara masyarakat perkotaan dan pedesaan di daerah-daerah yang sudah maju. Masyarakat perkotaan di daerah yang sudah maju mempunyai kemampuan dan wawasan yang lebih tinggi akan teknologi informasi dibandingkan masyarakat perkotaan yang hidup di daerah kurang maju. Demikian pula, masyarakat pedesaan di daerah yang sudah maju, mereka akan mempunyai pengetahuan yang sedikit lebih tinggi untuk mengenal teknologi informasi dibanding masyarakat pedesaan di daerah yang kurang maju (bahkan tidak terjangkau jaringan komunikasi sama sekali).

b. Kekurangan skill Sumber Daya Manusia (SDM)

Kekurangan skill SDM disini bisa dikatakan sebagai minat dan kemampuan dari seseorang untuk menggunakan sarana digital. Masih banyak masyarakat yang merasa gugup, takut sehingga enggan menggunakan sarana digital seperti komputer atau laptop.

c. Kekurangan isi/materi berbahasa Indonesia

Konten berbahasa Indonesia menentukan bisa tidaknya seorang dapat mengerti mengakses internet, di Indonesia terutama kota-kota tingkat pendidikan sudah lebih tinggi. Jadi, sedikit banyak sudah mengerti bahasa Inggris. Sedangkan yang di desa, seperti petani-petani, mereka masih sangat kurang dalam menggunakan bahasa asing (Inggris).

d. Kurangnya pemanfaatan internet itu sendiri

Berbicara mengenai kesenjangan digital, bukanlah semata-mata persoalan infrastuktur. Banyak orang memiliki komputer, bahkan setiap hari, setiap jam- bisa mengakses Internet tetapi "tidak menghasilkan apapun". Misal, ada seorang remaja punya akses ke komputer dan Internet. Tapi yang dia lakukan hanya Chatting yang biasa-biasa saja. Tentu saja, ia tidak bisa menikmati keuntungan-keuntungan 
yang diberikan oleh teknologi digital. Itu artinya, kesenjangan digital tidak hanya bisa dijawab dengan penyediaan infrastruktur saja. Infrastruktur tentu dibutuhkan tetapi persoalannya adalah ketika orang punya komputer dan bisa mengakses Internet, pertanyaan berikutnya adalah, "apa yang mau diakses? Apa yang mau dia kerjakan dengan peralatan itu, dengan keunggulan-keunggulan teknologi itu.

\section{DIGITAL DIVIDE PADA PER- EMPUAN INDONESIA}

TIK yang berkembang saat ini begitu dahsyat dan maju sehingga diharapkan dapat menjembatani kesenjangan digital secara cepat serta mengakibatkan teknologi menjadi semakin murah. Oleh karenanya teknologi ini diharapkan memberikan manfaat lebih bagi kaum miskin. Walaupun demikian, jika TIK ini tidak dengan cepat mengikutsertakan kaum marjinal dunia dengan memberikan manfaat utama bagi mereka, maka justru teknologi ini akan membuat mereka semakin terpinggirkan. Di negara berkembang kaum marjinal sebagaian besar adalah perempuan maka kecuali dilakukan usaha untuk menghilangkan kesenjanagan, akan ada resiko bahwa TIK justru akan memperbesar kesenjangan gender dan dampak positif dari TIK justru tidak akan tercapai.

Hambatan dalam dunia TIK memberikan permasalahan yang lebih besar bagi perempuan di mana mereka tidak paham berbahasa Inggris, kurang kesempatan mendapatkan pelatihan di bidang komputer, beban pekerjaan rumah tangga yang cukup berat, ekonomi masih lemah, masih mengalami hambatan budaya, dan terakhir, konten dibidang TIK masih kurang relevan bagi kehidupan perempuan secara umum. Semua hambatan hambatan ini akan lebih memarjinalkan mereka dari sector TIK ini.
Beberapa hambatan bagi perempuan Indonesia untuk mengakses teknologi informasi di beberapa negara berkembang (developing countries) diantaranya:

a. Kondisi geografis secara umum mempengaruhi akses perempuan terhadap informasi teknologi di negara berkembang. Pada sebagian masyarakat, mobilitas perempuan jauh lebih terbatas dibandingkan dengan laki-laki. Mobilitas ini akan lebih terbatas lagi di masyarakat konservatif dimana adat istiadat agama atau sosial tidak mengizinkan perempuan untuk melakukan perjalanan di tempat umum tanpa pengawasan laki-laki.

b. Perempuan mengalami hambatan yang lebih tinggi di bidang TIK karena mereka lebih banyak yang masih buta huruf, akses pendidikan dan informasi yang minim, kurang meratanya pelatihan TIK, kurangnya waktu, dan kurangnya sarana ekonomi dan keuangan. Bahkan dibeberapa tempat, perempuan dilarang masuk di internet center atau arena publik dengan fasilitas TIK.

c. Perempuan masih kurang terwakili di sektor swasta, lembaga pemerintah dan bidang public lainnya, yang umumnya mengontrol sektor TIK. Sehingga di bidang TIK, masih jarang yang memperhatikan kebutuhan khusus bagi perempuan, terutama karena kurangnya perhatian dari para pengambil kebijakan di bidang TIK.

d. Industri TIK sebagian besar di kontrol oleh laki-laki, dan ini terlihat dari lebih banyaknya lakilaki yang menjadi eksekutif atau 
direksi. Disektor swasta, perempuan kurang menjadi pemilik atau pengambil keputusan utama, atau memberikan pengaruh dalam pengambilan keputusan, sedangkan di korporasi, perempuan eksekutif masih harus berjuang untuk menembus "the glass ceiling" (batasan yang tidak terlihat)

e. Di bidang ranah public/media, masih banyak perempuan yang tersubordinasi dengan image dan stereotype yang negatif dan seksi, dan masih kurang usaha dan perjuangan untuk menghapuskan image negatif ini.

f. Budaya patriarki yang menempatkan laki-laki selalu dikaitkan dengan tugas dan fungsi di luar rumah sedangkan perempuan yang berkodrat melakukan dan mengurus anak. Budaya patriarki pun terasa di bidang teknologi. Hingga saat ini tidak cukup ramah terhadap perempuan. Masih terdapat anggapan bahwa teknologi menjadi tugas laki-laki dan merupakan ranah maskulin. Sehingga dunia teknologi informasi masih merupakan "male dominated".

Jika kita membandingkan peran perempuan Indonesia dalam pemanfaatan TIK sangat jauh tertinggal dari negaranegara tetangga. Hal ini tidak mengherankan mengingat perempuan Indonesia masih terkungkung dengan budaya patriarki. Perempuan Indonesia masih dianggap sebagai "kanca wingking" yang selalu bersinggungan dengan ranah domestik. Berbeda dengan negara lain seperti Singapura dan Malaysia, dimana perempuan diberikan hak asasi yang sama seperti laki-laki dalam mengekpresikan potensi yang dimiliki. Oleh sebab itulah dipandang perlu untuk membuat perempuan melek Teknologi dan Informasi demi meningkatkan potensi bangsa.

\section{UPAYA MEMPERSEMPIT DIGITAL DIVIDE PADA PEREMPUAN INDONESIA}

Digital Divide saat ini telah menjadi sorotan dan dikhawatirkan akan mengancam pembangunan internasional. Setelah Summit Okinawa pada Agustus 2000, Kelompok Delapan negara mendirikan Digital Taskforce pada berbagai bidang untuk menghilangkan kesenjangan digital tersebut. Bahkan, PBB menekankan jika akses perempuan dalam bidang teknologi informasi sebagai masalah ketiga yang menjadi isu paling penting yang dihadapi perempuan secara global, setelah kemiskinan dan kekerasan terhadap perempuan. Mengingat pentingnya masalah ini, sudah saatnya untuk melakukan tindakan guna memastikan bahwa perempuan di negaranegara berkembang dapat mengaktifkan dirinya di era informasi. Dengan demikian akan ada banyak kesempatan bagi perempuan untuk dapat meningkatkan taraf hidup dan keluargnya.

Adapun upaya untuk mempersempit digital divide pada perempuan diantaranya:

a. Memberikan pemahaman pada perempuan akan pentingnya TIK (literasi informasi). The Prague Declaration (Unesco, 2003) menyatakan bahwa literasi informasi merupakan bagian dari kebutuhan informasi seseorang dan merupakan suatu kemampuan dalam mengidentifikasi, menempatkan, mengevaluasi, mengorganisasi dan untuk meng-efektifkan informasi yang ada untuk menyelesaikan masalah, dan diperlukan kembali untuk berpartisipasi secara efektif dalam masyarakat informasi, 
dan juga merupakan bagian dari dasar hak asasi manusia dalam long life education yang harus terus dikembangkan. Adapun manfaat dari literasi informasi menurut Hancock (2004) adalah: (a) membantu mengambil keputusan, literasi informasi berperan dalam membantu memecahkan suatu persoalan; (b) menjadi manusia pembelajar di era ekonomi pengetahuan, literasi informasi berperan penting dalam meningkatkan kemampuan seseorang menjadi manusia pembelajar; (c) menciptakan pengetahuan baru, literasi informasi berperan dalam menciptakan pengetahuan baru berdasarkan pemahamannya.

b. Menghilangkan diskriminasi gender Adanya pola sikap yang demikian menyebabkan adanya kesenjangan gender. Kesenjangan gender tidak pernah terjadi secara sengaja, tetapi terjadi karena adanya perlakuan yang gender diskriminatif. Oleh sebab itulah perlu menghilangkan perlakuan yang berbeda bagi perempuan agar mereka mendapatkan akses, kesempatan, fasilitas dan sumberdaya yang sama layaknya laki-laki.

c. Membangun kebijakan dan budaya gender yang transformatif. Kebijakan dan budaya gender yang transformatif memberikan sarana yang memberdayakan perempuan dengan memberikan mereka kesempatan dan kontrol terhadap TIK, menentukan jenis TIK apa yang mereka butuhkan, dan membungkusnya dengan kebijakan yang mendukung perempuan untuk mencapai tujuannya. Pendekatan dengan dimensi sosial ini dibutuhkan untuk diintegrasikan kedalam pola pengambilan keputusan yang berdampak terhadap peran perempuan di bidang TIK.

d. Meningkatkan skill dan kompetensi dengan Bimtek TIK. Menyadari akan pentingnya peran perempuan dalam pemanfaatan TIK untuk tujuan produktif, maka perlu ada bimbingan teknis (bimtek) TIK untuk komunitas perempuan. Bimbingan teknis ini diharapkan dapat meningkatkan kesadaran (awarness), pembelajaran (leraning), penerapan dalam kehidupan pribadi dan masyarakat (implementation), serta mampu mensosialisasikan (sosialization) penggunaan TIK

\section{KESIMPULAN}

Isu tentang kesenjangan telah menjadi isu yang sangat banyak menuai berbagai macam perdebatan, yang pada dasarnya perihal bagaimana melihat kesenjangan itu. Kesenjangan digital merupakan ketidaksamaan dalam hal akses pada komputer dan internet antara kelompok yang didasarkan pada satu atau lebih identifikasi sosial dan kultural. Sebagai contoh kesenjangan digital adalah perbedaan akses pada komputer dan internet antara kelompok perempuan dan laki-laki. Beberapa faktor yang menyebabkan digital divide kaum perempuan yaitu tingkat ketrampilan dan pendidikan, masalah bahasa, keterbatasan waktu dan norma budaya dan sosial.

Mengingat pentingnya masalah ini, sudah saatnya untuk melakukan tindakan guna memastikan bahwa perempuan di negara-negara berkembang dapat mengaktifkan dirinya di era informasi. Adapun upaya untuk mempersempit digital divide pada perempuan diantaranya: (1) memberikan pemahaman pada perempuan akan pentingnya TIK (literasi informasi); (2) menghilangkan diskriminasi gender; (3) membangun kebijakan dan budaya gender yang transformative; dan (4) meningkatkan skill dan kompetensi dengan Bimtek TIK.

\section{DAFTAR RUJUKAN}


Dholakia, R.R., N. and Kshetri, N. 2003. Gender and Internet Usage. University of Rhode Island

Enochsson, A. 2005. A Gender Perspective On Internet Use: Consequences For Information Seeking. The Interactive Institute, Stockholm, Information Research, 10(4) paper 237

Gefen, D. dan Straub, D.W. 1997. Gender Differences in the Perception and Use of E-mail: An Extension to the Technology Acceptance Model. MIS Quarterly.

Hancock, Vicki E. 2004. Information Literacy for Lifelong Learning, (online), (http://www.libraryinstruction.com/informationliteracy.html, diakses 10 Mei 2016.

Haag dan Keen. 1996. Information Technology: Tomorrow's Advantage Today. Hammond: Mcgraw-Hill College

ITU. 2014. Measuring the Information Society Report. Geneva: Information and Technology Union.

Kompas, Kamis 31 Maret 2016

Martin, E. 1999. Managing Information Technology What Managers Need to Know (3rd ed). New Jersey: Pearson Education International.

OECD. 2001. OECD Annual Report 2001. Paris: OECD Publishing.

Parayil, G. 2005. The Digital Divide and Incresing Returns; Contradiction of Information Capitalism. The Information Society, No. 21
Ramilo, C. 2002. National ICT Policies and Gender Equality Regional Perspective: Asia", United Nations Division for the Advancement of Women (DAW) Expert Group Meeting on "Information and communication technologies and their impact on and use as an instrument for the advancement and empowerment of women".

Unesco. 2003. The Prague Declaration "Towards An Information Literate Society", (online), (http://www.nclis.gov/libinter/infolitconf\&meet/postinfolitco nf\&meet/praguedeclaration.p df diakses 8 Mei 2016)

UNDP. 2011. Human Development Report - Sustainability and Equity: A Better Future for All.

Williams dan Sawyer. 2003. Using Information Technology: A Practical Introduction to Computers and Communications. London: Career Education 